\title{
Surrogate tree cavities: boxes with artificial substrate can serve as temporary habitat for Osmoderma barnabita (Motsch.) (Coleoptera, Cetoniinae)
}

\author{
Jacek Hilszczański • Tomasz Jaworski • \\ Radosław Plewa $\cdot$ Nicklas Jansson
}

Received: 24 April 2014/ Accepted: 21 August 2014/Published online: 28 August 2014

(C) The Author(s) 2014. This article is published with open access at Springerlink.com

\begin{abstract}
Many saproxylic insects have declined or became extinct, mainly due to habitat loss and fragmentation, and their survival increasingly depends on active conservation. Efforts to achieve this goal may be supported by the introduction of new methods, including creation of artificial habitats. Here we present results of studies on the use of wooden boxes mimicking tree cavities for an endangered saproxylic species, Osmoderma barnabita. Boxes were filled with the feeding substrate for larvae and installed on trees. Second and third-instar O. barnabita larvae were introduced in half of the boxes; the remaining ones were left uninhabited. Later inspection of boxes showed a high survival rate of introduced larvae, as well as successful breeding of a new generation inside the boxes. At the same time boxes were not colonized by the local population of $O$. barnabita, although other cetoniids did so. The co-occurring larvae of other cetoniids did not affect $O$. barnabita larvae. Thermal conditions inside boxes and natural tree cavities were almost identical and based on the results of our studies we conclude that wooden boxes may serve as temporary habitat for $O$. barnabita. They may be particularly useful in cases of destruction of species' natural habitat, in restoration programs, and have the potential to act as a 'stepping stones' in cases of a lack of habitat continuity.
\end{abstract}

J. Hilszczański · T. Jaworski $(\bowtie) \cdot$ R. Plewa

Department of Forest Protection, Forest Research Institute,

Sękocin Stary ul. Braci Leśnej 3, 05-090 Raszyn, Poland

e-mail: t.jaworski@ibles.waw.pl

N. Jansson

Department of Physics, Chemistry and Biology, Linköping

University, 58183 Linköping, Sweden
Keywords Artificial habitat $\cdot$ Hollow trees $\cdot$ Saproxylic insects $\cdot$ Conservation method $\cdot$ Protaetia $\cdot$ Cetonia

\section{Introduction}

The number of old hollow trees in Europe has been dramatically reduced the last 100 years (Kirby et al. 1995) resulting in a decline of many cavity-living species. The reduction of these habitats is mainly an effect of changes in forestry, where production of healthy trees for economic purposes was a priority since the introduction of modern forest management from the 19th century (Speight 1989). Additionally, changes in agricultural systems has reduced areas of wood pasture and pollarded trees have declined and veteran trees have disappeared. Furthermore, management in commercial forests and natural succession in many protected areas leads to canopy closure, which has decreased habitat quality for many saproxylic organisms. As a result many of the cavity-living species are mainly found today in the few remaining open habitats such as the last wood pastures, parks, and avenues (Ranius et al. 2005; Oleksa 2009).

One of these species is the hermit beetle Osmoderma eremita (Scopoli). It is a red listed species (VU-vulnerable) protected by law in Poland as well as in many European countries (Szwałko 2004). The species is regarded as near threatened (NT) according to the IUCN Red List (IUCN 2014). Furthermore the species is treated as a "special concern" and listed in annexes of the Habitat Directive of the European Union (92/43/EU). Recent taxonomic revisions and research have revealed the status of the genus Osmoderma occurring in Europe. Most probably in Poland the genus Osmoderma is represented mainly by Osmoderma barnabita (Audisio et al. 2009; Oleksa et al. 2012). This 
taxonomic reappraisal should enforce correction of the Habitat Directive where the whole genus Osmoderma needs to be included.

Osmoderma is a typical tree cavity inhabitant and its occurrence is strongly dependent on the presence of old hollow trees of appropriate quality, relating to sun exposure (but see: Chiari et al. 2012a, b; Jönsson 2003) and a high volume of wood mould, where larvae of the species develop (Ranius and Nilsson 1997; Ranius 2002; Oleksa et al. 2007). The species is distributed over much of Europe and is mostly found in oaks (Quercus spp.), but can also inhabit many other tree species (Ranius et al. 2005).

One of the main threats for Osmoderma is removal of trees with cavities, often for safety reasons in parks, avenues, and graveyards, or during road reconstruction (Carpaneto et al. 2010). Incidental felling of cavity containing trees with larvae of Osmoderma also happens in commercially managed forests. Another problem for Osmoderma arises from its poor dispersal abilities (Ranius and Hedin 2001; Chiari et al. 2012a, b); therefore isolated populations have difficulties to colonise new suitable sites by natural movement.

The habitat of Osmoderma is protected in the European Union, but in cases whereby single trees or whole local habitats have been erased, temporary settlement of larvae in boxes mimicking natural cavities, until they can complete full development, would be of great value for conservation of the species. Creating artificial habitats for cavity-living saproxylic organisms has been tested on a small scale in England with promising effects (Green 1995). In Sweden a large scale experiment with boxes for saproxylic beetles was conducted in oak habitats. As a result, over 100 species of saproxylic beetles have been reared in this way, including several red-listed ones (Jansson et al. 2009).

The main goal of the study was to evaluate the effectiveness of boxes with artificial substrate for the development of introduced $O$. barnabita larvae. We also wanted to determine whether the boxes are attractive for local populations of $O$. barnabita and other cetoniids.

\section{Materials and methods}

Study sites

The study was conducted in four Forest Districts in northeastern and western Poland, i.e. Miłomłyn $\left(53^{\circ} 46^{\prime} \mathrm{N}\right.$; $\left.19^{\circ} 50^{\prime} \mathrm{E}\right)$, Dobrocin $\left(53^{\circ} 54^{\prime \prime} \mathrm{N} ; 1^{\circ} 50^{\prime} \mathrm{E}\right)$, Krotoszyn $\left(51^{\circ} 41^{\prime} \mathrm{N} ; 17^{\circ} 21^{\prime} \mathrm{E}\right)$ and Łopuchówko $\left(52^{\circ} 32^{\prime} \mathrm{N} ; 16^{\circ} 55^{\prime} \mathrm{E}\right)$. One study site was selected in each locality, except for Krotoszyn, with two study sites. The study sites were selected based on the presence of natural populations of $O$. barnabita (Bunalski, Oleksa and Gawroński, pers. comm; own observations). Study sites were located within a forest avenue of lime (Tilia cordata, 1 site in Miłomłyn), old oak forests (Quercus robur, 2 sites in Krotoszyn and 1 site in Łopuchówko) and mixed beech (Fagus sylvatica)—oak forest (1 site in Dobrocin).

\section{Box design and location}

In general box construction was similar to that which was applied in a previous study (Jansson et al. 2009). Boxes $(70 \times 40 \times 30 \mathrm{~cm}=$ ca. 841$)$ were built using $3 \mathrm{~cm}$ thick oak boards (Fig. 1). In the front wall of each box an entrance hole of $3 \mathrm{~cm}$ in diameter was made approximately $10 \mathrm{~cm}$ below the top cover. A fitted plastic container (30 $\mathrm{cm}$ high) was placed inside to retain moisture. Boxes were filled ( $80 \%$ ) with substrate consisting of oak sawdust and fallen oak leaves (1:1) with the addition of some five litres of water.

Altogether 40 boxes were used in the study. All boxes were installed on trunks of thicker trees (diameter at breast height usually more than $50 \mathrm{~cm}$ ), situated along the roads or at the edge of stand. Eight boxes (1 box/tree) spaced within 20-100 m were installed in each study site, within a distance of less than $200 \mathrm{~m}$ from the nearest tree occupied by $O$. barnabita. Boxes were attached to the trunk with metal wire, at a height of about 4-5 m (Fig. 1), and were always situated on the southern or south-western part of the trunk.

\section{Experiment}

Second and third-instar $O$. barnabita larvae were collected in 2010 and 2011 from hollow trees felled by wind or cut during road constructions. For each study site we used larvae collected from trees situated within a maximum distance of ca. $50 \mathrm{~km}$. Larvae introduced in a given box originated from one tree. Altogether 114 larvae were introduced to 20 boxes -12 and 8 boxes in 2010 and 2011, respectively (Table 1). The remaining 20 boxes used in the experiment were left without any larvae. Boxes were visited once a year and refilled with substrate if necessary. During the final inspection in the field in May 2012 larvae of $O$. barnabita were distinguished from other cetoniids by morphological characteristics (see: Medvedev 1960; Shabalin and Bezborodov 2009; Oleksa et al. 2012) and classified with respect to instar. To avoid misidentifications, larvae of other cetoniids were identified only to the level of subfamily. Health condition of $O$. barnabita larvae was roughly assessed in the field, based on their mobility and body turgor. Thus, larvae were categorized as: healthy (larvae viable, strong turgor), sick (weak movement and body turgor) or dead (no movement, body decomposing). 
Fig. 1 Box design and its mounting on a tree

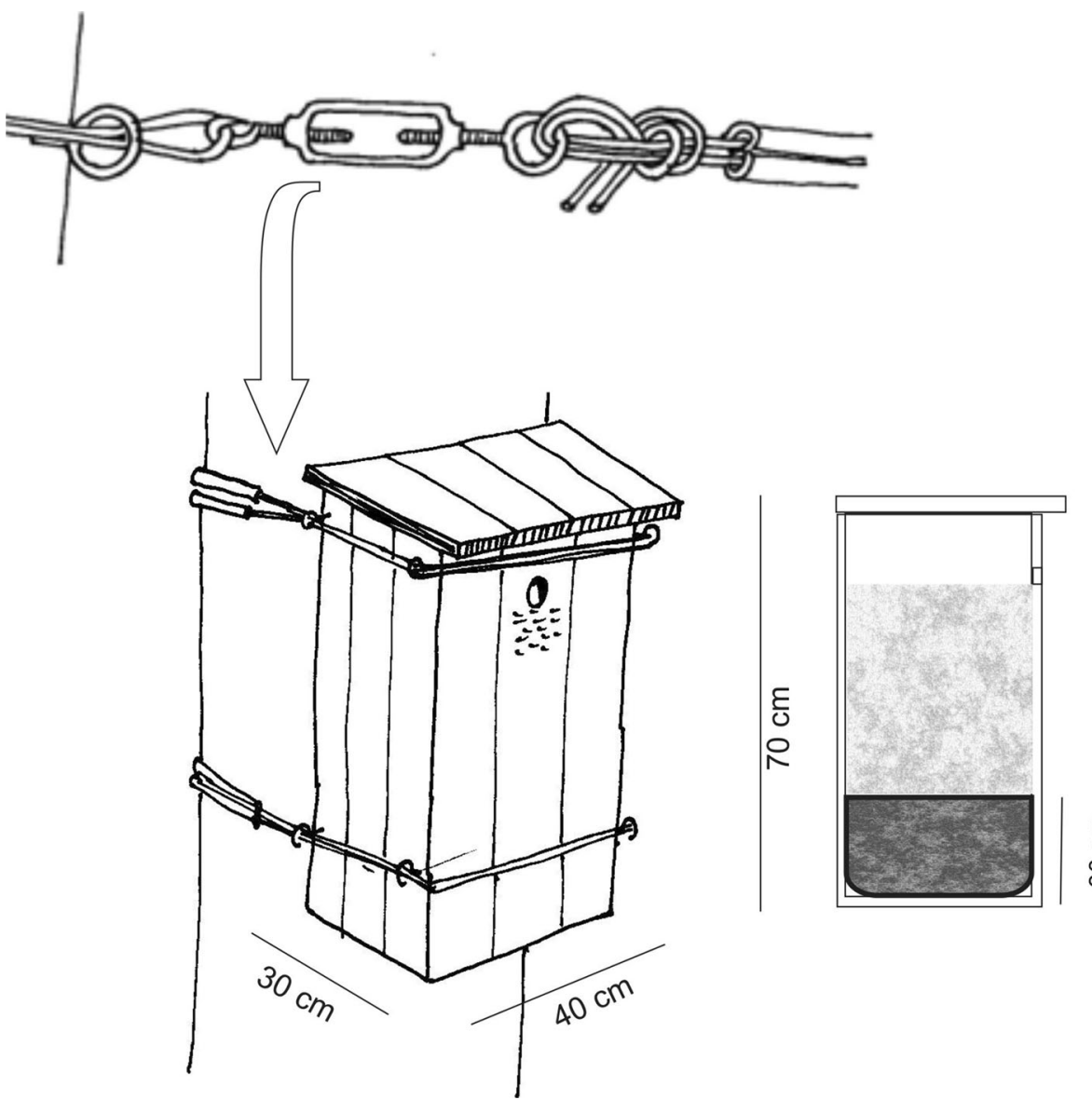

ह్
Pupae of $O$. barnabita were not classified in respect of health conditions, except for cases when pupal chambers were found opened.

\section{Temperature}

Thermal conditions in one artificial box and one natural tree hollow were measured using two data loggers put for the whole year inside the box and natural tree cavity at one study site. We used HOBO Pendant Temperature/Light Data Logger 64 K - UA-002-64 (Onset Computer Corporation), set to $1 \mathrm{~h}$ recording intervals. Loggers were placed about $15 \mathrm{~cm}$ deep in the substrate.

Data analyses

The possible effect of interspecific competition between $O$. barnabita and other cetoniids was investigated by testing the correlation between total number of pupae and larvae of both taxa found during the final inspection in boxes with introduced larvae of $O$. barnabita. Dead and sick larvae and pupae of $O$. barnabita were omitted from the analysis. To answer the question whether the presence of $O$. barnabita larvae affects the occurrence of other cetoniids we compared the number of their pupae and larvae found both in boxes with introduced larvae of $O$. barnabita and in control boxes. Differences between thermal conditions in the artificial box and natural tree cavity were analysed based on values of average daily temperatures collected from a period of 367 days. Since the assumptions of normality of variables were not fulfilled, we used Spearman's rank correlation coefficient and Mann-Whitney U test for the analyses. All analyses were performed at $\alpha=0.05$ using Statistica 8 (StatSoft Inc.).

\section{Results}

Larvae of $O$. barnabita survived in 18 of 20 settled boxes (90\%) and in two boxes their number was higher than initially introduced (boxes 1 and 12; see Table 1). Of the remaining two boxes one was lost during the experiment and one was found to be without any larvae. During the final inspection, 111 healthy larvae, as well as 28 pupal chambers of $O$. barnabita were found. In all 20 settled boxes we found only one dead larva, and 5 individuals were classified as sick. One of the 20 control boxes was lost 
Table 1 Results of rearing $O$. barnabita larvae in boxes with artificial substrate

\begin{tabular}{|c|c|c|c|c|c|c|c|c|}
\hline \multirow[t]{2}{*}{ Box no. } & \multicolumn{2}{|c|}{$\begin{array}{l}\text { No. of } O . \text { barnabita } \\
\text { larvae introduced }\end{array}$} & \multicolumn{3}{|c|}{$\begin{array}{l}\text { No. of } O \text {. barnabita larvae and pupae } \\
\text { found after final inspection }\end{array}$} & \multicolumn{2}{|c|}{$\begin{array}{l}\text { No. of other cetoniid larvae and } \\
\text { pupae after final inspection }\end{array}$} & \multirow[t]{2}{*}{ Remarks } \\
\hline & $\mathrm{L}_{2}$ & $\mathrm{~L}_{3}$ & $\mathrm{~L}_{2}$ & $\mathrm{~L}_{3}$ & $p$ & $\mathrm{~L}$ & $p$ & \\
\hline 1 & - & $6^{\mathrm{a}}$ & 25 & - & - & - & - & - \\
\hline 2 & - & - & - & - & - & 14 & - & - \\
\hline 3 & $4^{\mathrm{a}}$ & $4^{\mathrm{a}}$ & - & 1 sick & 1 & 8 & - & - \\
\hline 4 & $4^{a}$ & $4^{\mathrm{a}}$ & - & 1 dead & - & - & - & - \\
\hline 5 & - & - & - & - & - & - & - & - \\
\hline 6 & - & - & - & - & - & 4 & - & - \\
\hline 7 & $4^{\mathrm{a}}$ & $4^{\mathrm{a}}$ & - & 2 sick & 1 empty & 77 & - & $\mathrm{TN}$ \\
\hline 8 & $4^{\mathrm{a}}$ & $4^{a}$ & 3 & - & 1 sick & 52 & - & - \\
\hline 9 & - & - & - & - & - & 38 & - & $\mathrm{TN}$ \\
\hline 10 & - & - & - & - & - & 77 & - & - \\
\hline 11 & - & - & - & - & - & - & - & box lost \\
\hline 12 & $4^{\mathrm{a}}$ & $3^{\mathrm{a}}$ & 65 & 3 & 1 & 52 & - & $\mathrm{TN}$ \\
\hline 13 & $4^{\mathrm{a}}$ & $4^{\mathrm{a}}$ & - & - & - & - & - & box lost \\
\hline 14 & $5^{\mathrm{a}}$ & $3^{\mathrm{a}}$ & - & - & - & 31 & 10 & - \\
\hline 15 & - & - & - & - & - & 56 & 4 & - \\
\hline 16 & - & - & - & - & - & 21 & - & $\mathrm{TN}$ \\
\hline 17 & - & $4^{b}$ & - & 2 & 1 & - & - & AN \\
\hline 18 & - & - & - & - & - & - & - & $\mathrm{TN}, \mathrm{AN}$ \\
\hline 19 & - & - & - & - & - & - & - & $\mathrm{TN}$ \\
\hline 20 & - & $3^{\mathrm{b}}$ & - & 2 & 1 & 2 & - & $\mathrm{TN}$ \\
\hline 21 & - & $3^{\mathrm{b}}$ & - & 1 & 2 & - & - & AN \\
\hline 22 & - & - & - & - & - & - & - & $\mathrm{TN}$ \\
\hline 23 & - & $3^{\mathrm{b}}$ & - & 3 & - & - & - & $\mathrm{TN}$ \\
\hline 24 & - & - & - & - & - & - & - & AN \\
\hline 25 & - & - & - & - & - & 13 & - & - \\
\hline 26 & - & $6^{\mathrm{a}}$ & - & 2 sick & 2 & - & - & $\mathrm{TN}$ \\
\hline 27 & - & - & - & - & - & - & - & - \\
\hline 28 & - & $6^{\mathrm{a}}$ & - & - & 2 & 3 & - & - \\
\hline 29 & - & - & - & - & - & - & - & $\mathrm{TN}$ \\
\hline 30 & - & $6^{\mathrm{a}}$ & - & - & 4 & 55 & - & - \\
\hline 31 & - & - & - & - & - & - & - & $\mathrm{TN}$ \\
\hline 32 & - & $6^{\mathrm{a}}$ & - & - & 6 & 23 & - & $\mathrm{TN}$ \\
\hline 33 & - & - & - & - & - & - & - & - \\
\hline 34 & - & $4^{\mathrm{b}}$ & - & 1 & 3 & - & - & $\mathrm{NN}$ \\
\hline 35 & - & - & - & - & - & - & - & $\mathrm{TN}$ \\
\hline 36 & - & $4^{\mathrm{b}}$ & - & 2 & - & - & - & - \\
\hline 37 & - & - & - & - & - & - & - & - \\
\hline 38 & - & $4^{\mathrm{b}}$ & - & 3 & - & - & - & $\mathrm{BN}, \mathrm{TN}$ \\
\hline 39 & - & - & - & - & - & - & - & $\mathrm{TN}$ \\
\hline 40 & - & $4^{\mathrm{b}}$ & - & 1 & 3 & - & - & $\mathrm{TN}$ \\
\hline Total & 29 & 85 & 93 & 24 & 28 & 526 & 14 & - \\
\hline
\end{tabular}

Boxes 1-2 and 11-16: Forest District Miłomłyn, boxes 3-10: FD Dobrocin, boxes 17-32: FD Krotoszyn, boxes 33-40: FD Łopuchówko $A N$ ant nest, $B N$ bee nest, $T N$ titmouse (Parus major) nest, $N N$ nuthatch (Sitta europaea) nest

a larvae introduced in April 2010

b larvae introduced in June 2011 
Fig. 2 Average daily temperature in natural tree cavity and in artificial box, Forest District Krotoszyn

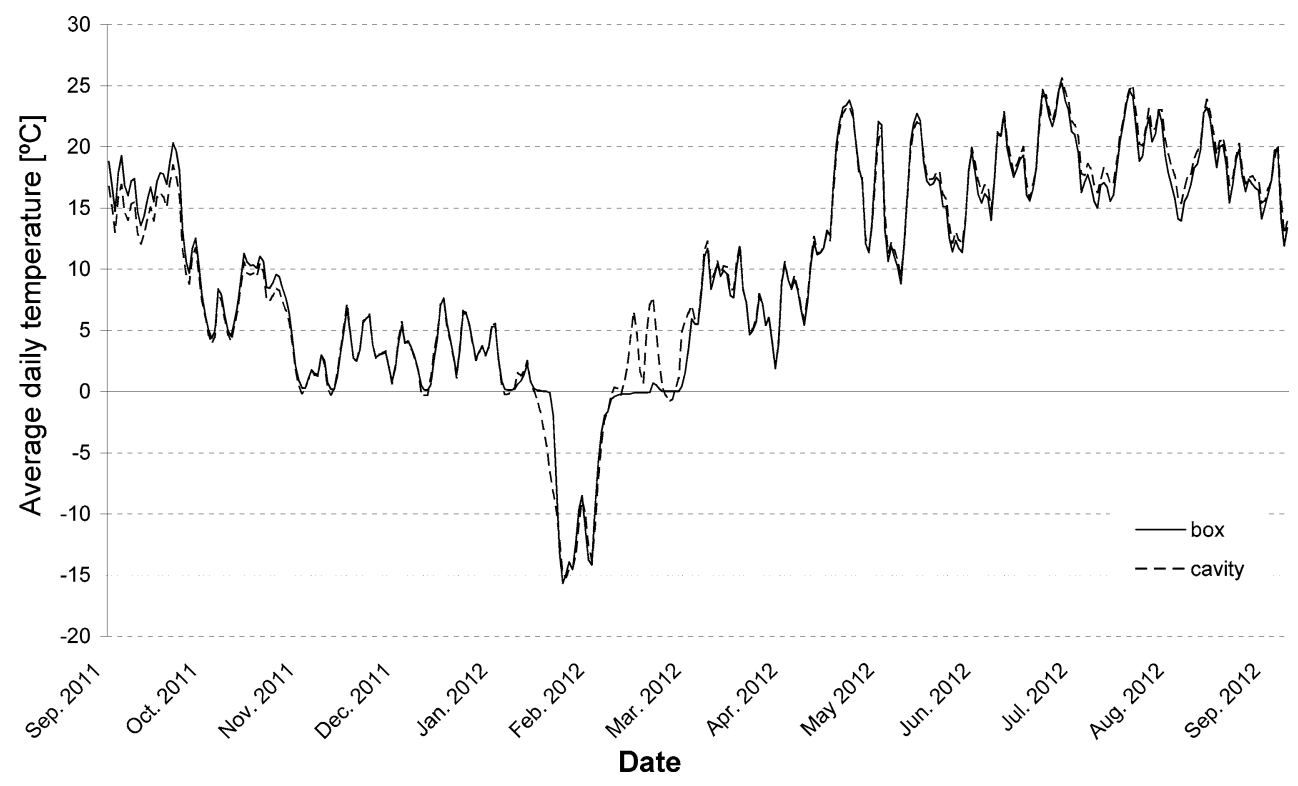

during the experiment. None of the remaining control boxes was colonized by $O$. barnabita.

Nine boxes with introduced $O$. barnabita larvae (45\%) and 7 control boxes (35\%) were colonized by other representatives of the subfamily Cetoniinae. Birds' nests were found in 8 boxes (40\%) with $O$. barnabita larvae and in 9 (45\%) control boxes. Single boxes of both types were found to be inhabited also by bees and ants (Table 1).

Comparison of the number of pupae and larvae of $O$. barnabita and other cetoniids found during final inspection showed no correlation between the two values (Spearman's rank correlation: $\mathrm{R}=0.041, p=0.865$ ). The occupancy rate (i.e., the number of boxes with larvae and pupae of other cetoniids) was slightly higher in boxes with introduced larvae of $O$. barnabita compared to control boxes ( 9 and 7 boxes, respectively). However the differences between number of these cetoniid larvae and pupae in both types of boxes were not significant (Mann-Whitney test: $\mathrm{U}=180, \mathrm{Z}=0.541, p=0.588$ ).

Differences between average daily temperatures in the box and natural tree cavity (Fig. 2) usually did not exceed $1{ }^{\circ} \mathrm{C}$ (283 days) or $2{ }^{\circ} \mathrm{C}$ (61 days) and were statistically not significant (Mann-Whitney test: $\mathrm{U}=66,197, \mathrm{Z}=$ $-0.399, p=0.689$ ). Instead, both variables were highly correlated (Spearman's rank correlation: $\mathrm{R}=0.984$, $p<0.0001$ ).

\section{Discussion}

Wooden boxes with artificial substrate may be an effective tool for the conservation of many saproxylic insects (Jansson et al. 2009). In our study the larvae of an endangered flagship species $O$. barnabita survived in the majority of tested boxes and in some of them we found large numbers of new individuals. This most likely resulted from the fact that introduced larvae completed their lifecycles and the adult beetles mated and females then laid eggs in the boxes. We cannot exclude also the possibility of attracting local females by males that emerged inside boxes, similarly to the closely related species $O$. eremita in which females are attracted to males in natural tree cavitites (Larsson et al. 2003).

Our study showed low attractiveness of artificial boxes as a breeding site for local populations of $O$. barnabita, as evidenced by no successful colonisation of control boxes. This result seems somewhat unexpected, given the fact that all the boxes were installed within range of dispersion of the adult $O$. barnabita, which, under the conditions of northern Poland, is estimated on average to be $500 \mathrm{~m}$ (Oleksa et al. 2013). On the other hand, our result is similar to that reported by Jansson et al. (2009) who, after three-year studies, observed colonization of $O$. eremita in only $2 \%$ of boxes. Lack of colonization of boxes by local beetles may be explained by low colonization capacity of the species in general, as only about $15-18 \%$ of adults leave their host-trees and seek nearby hollow trees (Ranius and Hedin 2001; Hedin et al. 2008). It may also be a result of absence of appropriate fungi inside boxes compared to natural tree hollows. Although the hermit beetle is considered rather a generalist in respect of tree species colonized (e.g. Ranius et al. 2005), associations with specific fungi may play an important role in the selection of appropriate microhabitats, as has been observed in many saproxylic beetles (Kaila et al. 1994; Leather et al. 2013). 
Interspecific competition is considered one of the most important factors affecting populations of insects inhabiting the same niches (Coulson et al. 1976; Denno et al. 1995; Kadowaki 2010; Weslien et al. 2011), therefore it should be expected also in the case of hollow-dwelling species. Unexpectedly, we were unable to reveal an influence of co-occurring cetoniid larvae on the survival of $O$. barnabita larvae, although both taxa have similar microhabitats requirements. Similar, in this respect, are the results of studies conducted by Chiari et al. (2014), who found no evidence of interspecific competition between larvae of $O$. eremita and other cetoniids in tree cavities.

Both types of boxes tested in our study, i.e. with and without introduced $O$. barnabita larvae, were successfully colonized by other representatives of the subfamily Cetoniidae. The high effectiveness of these Cetoniidae in colonising boxes should probably be explained by their high dispersal abilities, as well as their higher population densities in the studied localities. This phenomenon was also observed by Jansson et al. (2009) who found adults of Protaetia marmorata in $10 \%$, and Potosia cupraea in $2 \%$ of studied boxes, and yet, as the larvae were not analyzed in his study, colonization of boxes by Cetoniidae might have been even higher. Interestingly, boxes with introduced larvae of $O$. barnabita were even more frequently colonized than control boxes, which may also confirm the absence of interspecific competition between the two taxa. Another interesting finding was that the presence of birds in boxes did not apparently affect the development of $O$. barnabita. Ranius and Nilsson (1997) reported an even higher frequency of Osmoderma occurrence in hollows with birds' nests, which may be explained by a higher nutrient content or better moisture conditions, as nest materials absorb water.

As evidenced by information from temperature data loggers put in an artificial box and in a natural tree cavity, thermal conditions were almost identical in both environments. Osmoderma larvae are known for their high freeze tolerance (Storey et al. 1993) and were able to survive most cold winter periods, when temperatures dropped far below $0{ }^{\circ} \mathrm{C}$ (Fig. 2). They are also resistant to drought (Ranius and Nilsson 1997; after Dajoz 1980) and were most probably not affected by high summer temperatures. Therefore, we conclude that artificial boxes resemble natural tree cavities with respect to temperature and, most probably, humidity.

\section{Conclusions}

Many saproxylic insects have become threatened due to habitat loss and fragmentation. Among them species with low dispersal abilities are especially vulnerable. The use of cavity-mimicking wooden boxes was recently studied and proved to be an effective method for conservation of many saproxylic beetles. The results of our studies showed that boxes with artificial feeding substrate may serve as a temporary habitat also for another endangered saproxylic insect, $O$. barnabita. Their use seems to be particularly feasible when existing habitat of the species is irreversibly damaged or there is a gap in its temporal or spatial distribution. One practical application of the boxes may be their use for possible restoration programs of $O$. barnabita. The introduced boxes with larvae, preferably collected from the closest existing populations, could thus initiate new population of the species in the area where it has disappeared, and where habitat quality is currently suitable. Therefore additional studies should be undertaken to develop detailed methodology for such actions (e.g. number of larvae and boxes used). Another perspective arises from the use of boxes as 'stepping-stones' that connect isolated populations of $O$. barnabita. However, poor colonisation rate of boxes by local populations also implies further work on improvement of their attractiveness for the adult beetles.

Acknowledgments The research was financed by the General Directorate of State Forests in Poland within the project "Hermit beetle Osmoderma eremita (Scop.) (Coleoptera, Scarabaeidae) in managed forests of Poland-habitat requirements and conservation capabilities". Authors would like to thank Andrzej Oleksa, Robert Gawroński and Marek Bunalski for fruitful discussions and help with finding sites for the experiments, as well as Mark Shaw for valuable comments on the manuscript and linguistic corrections. We also thank Wojciech Janiszewski (Forest Research Institute) for providing figure presented in the paper. We are grateful to Forest Districts involved in the project: Miłomłyn, Dobrocin, Krotoszyn and Łopuchówko with the Centre of Hermit beetle Conservation.

Open Access This article is distributed under the terms of the Creative Commons Attribution License which permits any use, distribution, and reproduction in any medium, provided the original author(s) and the source are credited.

\section{References}

Audisio P, Brustel H, Carpaneto GM, Coletti G, Mancini E, Trizzino M, De Biase A (2009) Data on molecular taxonomy and genetic diversification of the European hermit beetles, a species complex of endangered insects (Coleoptera: scarabaeidae, Cetoniinae, Osmoderma). J Zoolog Syst Evol Res 47:88-95

Carpaneto GM, Mazziotta A, Coletti G, Luiselli L, Audisio P (2010) Conflict between insect conservation and public safety: the case study of a saproxylic beetle (Osmoderma eremita) in urban parks. J Insect Conserv 14:555-565

Chiari S, Carpaneto GM, Zauli A, Marini L, Ranius T (2012a) Habitat of an endangered saproxylic beetle, Osmoderma eremita, in Mediterranean woodlands. Ecoscience 19:299-307

Chiari S, Carpaneto GM, Zauli A, Zirpoli GM, Audisio P, Ranius T (2012b) Dispersal patterns of a saproxylic beetle, Osmoderma eremita, in Mediterranean woodlands. Insect Conserv Diver 6:309-318 
Chiari S, Zauli A, Audisio P, Carpaneto GM (2014) Interactions between larvae of threatened saproxylic beetle Osmoderma eremita and other flower chafers in Mediterranean woodlands: implcations for conservation. Insect Conserv Diver [online first: doi: 10.1111/icad.12069]

Coulson RN, Mayyasi AM, Foltz JL, Hain FP (1976) Interspecific competition between Monochamus titillator and Dendroctonus frontalis. Environ Entomol 5:235-247

Dajoz R (1980) Écologie des insectes forestiers. Gauthier-Villars, Paris

Denno RF, McClure MS, Ott JR (1995) Interspecific interactions in phytophagous insects: competition reexamined and resurrected. Ann Rev Entomol 40:297-331

Green T (1995) Creating decaying trees. Br Wildl 6:310-311

Hedin J, Ranius T, Nilsson SG, Smith HG (2008) Restricted dispersal in a flying beetle assessed by telemetry. Biodiver Conserv $17: 675-684$

IUCN (2014) The IUCN Red List of Threatened Species. Version 2014.2. <http://www.iucnredlist.org >. Downloaded on 31 July 2014

Jansson N, Ranius T, Larsson A, Milberg P (2009) Boxes mimicking tree hollows can help conservation of saproxylic beetles. Biodiver Conserv 18:3891-3908

Jönsson N (2003) Situation and Habitat Preference of Hermit Beetle, Osmoderma eremita, on the Island Hallands Väderö. Inst. F. Entomologi, Swedish University of Agricultural Sciences, Uppsala

Kadowaki K (2010) Species coexistence patterns in a mycophagous insect community inhabiting the wood-decaying bracket fungus Cryptoporus volvatus (Polyporaceae: basidiomycota). Eur J Entomol 107:89-99

Kaila L, Martikainen P, Punttila YE (1994) Saproxylic beetles (Coleoptera) on dead birch trunks decayed by different polypore species. Ann Zool Fenn 31:97-107

Kirby KJ, Thomas RC, Key RS, McLean IFG (1995) Pasture woodland and its conservation in Britain. Biol J Linn Soc 56(Suppl):135-153

Larsson MC, Hedin J, Svensson GP, Tolasch T, Francke W (2003) Characteristic odor of Osmoderma eremita identified as a malereleased pheromone. J Chem Ecol 29:575-587

Leather SR, Baumgart EA, Evans HF, Quicke DLJ (2013) Seeing the trees for the wood-beech (Fagus sylvatica) decay fungal volatiles influence the structure of saproxylic beetle communities. Insect Conserv Diver 7:314-326

Medvedev SI (1960) Fauna of the USSR. Vol. 10, Issue 4. Coleoptera. Scarabaeidae. Subfamilies Euchirinae, Dynastinae, Glaphyrinae, Trichiinae. Acad Sci USSR, Moscow-Leningrad (in Russian)

Oleksa A (2009) Conservation and ecology of the hermit beetle Osmoderma eremita s.1. in Poland. In: Buse J, Alexander KNA,
Ranius T, Assmann T (eds) Saproxylic Beetles-their role and diversity in European woodland and tree habitats. In: Proceedings of the 5th Symposium and Workshop on the Conservation of Saproxylic Beetles. Pensoft Series Faunistica 89: 177-188

Oleksa A, Ulrich W, Gawroński R (2007) Host tree preferences of hermit beetles (Osmoderma eremita Scop., Coleoptera: scarabaeidae) in a network of rural avenues in Poland. Pol J Ecol 55:315-323

Oleksa A, Kadej M, Smolis A (2012) Chronione owady. Mieszkańcy alej i jak je chronimy. In: Tyszko-Chmielowiec P (ed) Aleje skarbnice przyrody. Eko Rozwój Wrocław, pp 53-80

Oleksa A, Chybicki IJ, Gawroński R, Svensson GP, Burczyk J (2013) Isolation by distance in saproxylic beetles may increase with niche specialization. J Insect Conserv 17:219-233

Ranius T (2002) Influence of stand size and quality of tree hollows on saproxylic beetles in Sweden. Biol Conserv 103:85-91

Ranius T, Hedin J (2001) The dispersal rate of a beetle, Osmoderma eremita, living in tree hollows. Oecologia 126:363-370

Ranius T, Nilsson SG (1997) Habitat of Osmoderma eremita (Coleoptera: scarabaeidae), a beetle living in hollow trees. J Insect Conserv 1:193-204

Ranius T, Aguado LO, Antonsson K, Audisio P, Ballerio A, Carpaneto GM, Chobot K, Gjurasin B, Hanssen O, Huijbregts H, Lakatos F, Martin O, Neculiseanu Z, Nikitsky NB, Paill W, Pirnat A, Rizun V, Ruicanescu A, Stegner J, Suda I, Szwalko P, Tamutis V, Telnov D, Tsinkevich V, Versteirt V, Vignon V, Vogeli M, Zach P (2005) Osmoderma eremita (Coleoptera, Scarabaeidae, Cetoniinae) in Europe. Anim Biodivers Conserv 28:1-44

Shabalin SA, Bezborodov VG (2009) Larvae of Scarab Beetles of the Subfamily Trichiinae (Coleoptera, Scarabaeidae) from the Russian Far East. Entomol Rev 89:1131-1136

Speight MCD (1989) Saproxylic Invertebrates and their Conservation. Council of Europe, Nature and Environment, Strasbourg 42

Storey KB, Churhill TA, Joanisse DR (1993) Freeze tolerance in hermit flower beetle (Osmoderma eremicola) larvae. J Insect Physiol 39:737-742

Szwałko P (2004) Osmoderma eremita. In: Głowaciński Z, Nowacki J (eds) Polska Czerwona Księga Zwierząt - Bezkręgowce. IOP PAN, Kraków-AR, Poznań, pp 103-104

Vera FWM (2000) Grazing Ecology and Forest History. CABI, Oxford

Weslien J, Djupström LB, Schroeder M, Widenfalk O (2011) Longterm priority effects among insects and fungi colonizing decaying wood. J Anim Ecol 80:1155-1162

Whitehouse NJ, Smith DN (2004) 'Islands' in Holocene forests: implications for Forest Openness, Landscape Clearance and 'Culture-Steppe' Species. Environ Archaeol 9:203-212 